\title{
Hubungan Gaya Kepemimpinan Kepala Madrasah dengan Kinerja Guru di Madrasah Aliyah Pondok Pesantren Al-Ikhlas Ujung Bone
}

\author{
Irfan Paizal, Arifuddin Siraj, Sitti Mania \\ Universitas Islam Negeri Alauddin Makassar, Indonesia \\ Jl. H.M. Yasin Limpo No. 36 Semata-Gowa, Tlp. 0411-1500365, Kodepos 92114 \\ Email: irfanpaizal@gmail.com, arifuddinsiraj@gmail.com, \\ sitti_mania@yahoo.com
}

\begin{abstract}
This research strive to present relationship of leadership style of headmaster with teachers' performance. This research aims to: 1) describe the reality of leadership style of headmaster; 2) describe the reality of teachers' performance; and 3) examine the correlation between leadership style of headmaster and teachers' performance at Madrasah Aliyah Pondok Pesantren Al-Ikhlas Ujung Bone. This research is a quantitative by ex post facto method. Instrument used is a questionarre than analyzed by using product moment correlation. This research indicate that: 1) leadership style of headmaster including the good category with percentage of $82,25 \%$; 2) teachers' performance including the high category with percentage of $84,21 \%$; and 3) the correlation between leadership style of headmaster and teachers' performance indicate a positive correlation with correlation coefficient value at 0,292 .
\end{abstract}

Keyword: Leadership Style, Headmaster and Teachers' Performance

Abstrak: Penelitian ini berupaya untuk menyajikan bagaimana hubungan gaya kepemimpinan kepala madrasah dengan kinerja guru. Penelitian ini bertujuan untuk: 1) mendeskripsikan realitas gaya kepemimpinan kepala madrasah; 2) mendeskripsikan realitas kinerja guru; dani 3) menguji korelasi antara gaya kepemimpinan kepala madrasah dengan kinerja guru di Madrasah Aliyahi Pondok Pesantren Al-Ikhlas Ujung Bone. Penelitian ini merupakan penelitian kuantitatif dengan metode ex post facto. Instrumen yang digunakan adalah angket, kemudian dianalisis menggunakan analisis korelasi product moment. Hasil penelitian ini menunjukkan bahwa: 1) gaya kepemimpinan kepala madrasah berada pada kategori baik dengan persentase sebesar $82,25 \%$; 2) kinerja guru berada pada kategori tinggi dengan persentase sebesar 84,21\%; dan 3) korelasi antara gaya kepemimpinan kepala madrasah dengan kinerja guru menunjukkan korelasi positifi yang berada pada tingkat hubungan rendah dengan nilai koefisien korelasi sebesar 0,292

Kata Kunci: Gaya Kepemimpinan, Kepala Madrasah dan Kinerja Guru 


\section{PENDAHULUAN}

Pendidikan merupakan suatu sistem dan proses yang melibatkan berbagai berbagai komponen. Adapun komponen tersebut meliputi komponen tujuan, pendidik, peserta didik, alat, lingkungan, kurikulum, dan evaluasi. Komponen yang satu dengan komponen yang lainnya saling kerjasama dalam mencapai suatu tujuan (Bukhari Umar, 2011: 5). Lulusan yang bermutu di dalam setiap madrasah sangat dipengaruhi oleh setiap mutu kegiatan pelaksanaan pembelajaran, sedangkan mutu kegiatan pembelajaran sangat ditentukan oleh berbagai faktor, di antaranya input peserta didik, kurikulum, pendidik dan tenaga kependidikan, sarana-prasarana, dana, manajemen, dan lingkungan yang saling berkaitan satu sama lain (Hery Widyatano, 204: 7). Oleh karena itu, kerja sama yang baik sangat diperlukan agar komponen yang ada di dalam lembaga pendidikan tersebut dapat menciptakan lulusan yang berkualitas.

Output lembaga pendidikan Islam yang merupakan kinerja lembaga pendidikan adalah prestasi lembaga pendidikan Islam itu sendiri yang dihasilkan dari hasil proses lembaga. Kinerja dalam lembaga pendidikan Islami dapat diukur dari kualitas efektivitas, produktivitas, efisiensi, inovasi, kualitas kehidupan kerja, serta moral kerjanya yang tetap pada nilai etika al-Qur'an. Hal tersebut sesui ajaran Islami bahwa manusia didorong untuk bekerja secara optimal dan komitmen terhadap proses dan hasil kerja (Baharuddin dan Umiarso, 2012: 262), sebagaimana firman Allah swt. dalam QS al-Sajadah/32: 7.

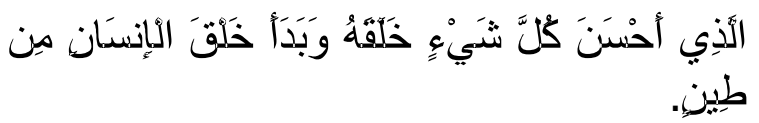

"Yang membuat segala sesuatu yang Dia ciptakan sebaik-baiknya dan yang memulai penciptaan manusia dari tanah" (Kementerian Agama RI, 2014: 416).
Berdasarkan ayat tersebut dapat dipahami bahwa Allah swt. telah menjelaskan kepada manusia, khususnya umat Islam bahwa mutu lembaga pendidikan Islam yang secara khusus dipandang bermutu jika mampu melahirkan keunggulan akademik dan nonakademik pada peserta didik yang dinyatakan lulus dari jenjang pendidikan atau penyelesaian program studi dengan nilai yang sangat memuaskan, serta memiliki kemampuan kognitif, keterampilan, dan emosional yang seimbang.

Terlaksananya pendidikan yang bermutu sangat ditentukan oleh guruguru yang bermutu pula, yaitu guru yang dapat melaksanakan tugasnya secara memadai (Supardi, 2015: 92). Salah satu yang menjadi indikator dalam suatu bangsa ditentukan oleh tingkat sumber daya manusia, sementara indikator sumber daya manusia ditentukan oleh tingkat pendidikan sumber daya manusia itu sendiri. Dengan demikian, semakin tinggi sumber daya manusia, semakin baik tingkat pendidikannya, demikian pula sebaliknya. Oleh karena itu, indikator tersebut sangat ditentukan oleh kinerja guru dalam menciptakan sumber daya manusia yang berkualitas.

Ukuran kinerja guru dapat terlihat dari rasa tanggung jawab dalam menjalankan amanah profesi yang diemban dan rasa tanggung jawab moral yang ada dipundaknya. Semua itu akan terlihat pada kepatuhan dan loyalitas dalam menjalankan tugas keguruan di dalam kelas dan di luar kelas (Sri Setiyati, 2014: 201). Uhar Suhar Saputra dalam Engkay Karweti mengatakan bahwa kinerja guru pada dasarnya merupakan suatu unjuk kerja yang dilakukan oleh guru dalam melaksanakan tugasnya sebaga pendidik (Uhar Suharsaputra, 2014: 77). Sebagaimana diketahu bahwa kinerja guru merupakan hasil kerja guru yang ditunjukkan dalam melaksanakan tugas, peran dan tanggung jawab 
berdasarkan kepada kecakapan serta pengalaman dan kesungguhannya. Namun, dalam hal ini kinerja guru yang berhubungan dengan tugasnya dalam mengajar. Secara ideal, guru yang diharapkan adalah guru yang memliki kemampuan mewujudkan kinerja yang dapat melaksanakan fungsi dan peranannya secara optimal. Perwujudan fungsi dan perannya secara optmal tersebut tercermin melalui keunggulannya dalam mengajar, hubungan dengan peserta didik, hubungan sesama rekan profesi, dan keterampilan profesionalnya.

Kinerja guru sebagaimana yang telah dikemukakan, yaitu berhubungan dengan tugas guru sebagai pengajar di madrasah. Kinerja guru yang baik tentunya tergambar pada penampilan kemampuan akademik maupun kemampuan non akademik. Artinya, guru mampu mengelola prosesi pembelajaran di dalam kelas dan mendidik peserta didik di luar kelas dengan sebaik-baiknya demi mencapai hasil belajar yang maksimal. Kemampuan guru yang banyak hubungannya dengan usaha meningkatkan proses dan hasil belajar, yaitu merencanakan program pembelajaran, melaksanakan dan mengelola proses pembelajaran, serta menilai kemajuan proses pembelajaran (Aan Hasanah, 2012: 17). Kinerja harus ditunjukkan guru pada saat membuat perencanaan pembelajaran, pelaksanaan pembelajaran, dan sampai melakukan evaluasi pembelajaran itu sendiri. Namun, seorang guru tidak akan sanggup untuk menunjukkan suatu kinerjanya pada saat melaksanakan tugasnya sebagai tenaga pendidik sehingga memerlukan faktor pendukung yang ada di dalam lingkungan madrasah itu sendiri, seperti gaya kepemimpinan kepala madrasah. Gaya kepemimpinan kepala madrasah yang baik akan tercipta hubungan yang baik dan akan memberikan pengaruh terhadap kinerja guru dalam menjalankan tugasnya sebagai pendidik di suatu madrasah. Kepemimpinan sebagai kemampuan seseorang atau pemimpin, untuk mempengaruhi perilaku orang lain menurut keinginan-keinginannya dalam suatu keadaan tertentu (Geoger R. Teryy, 2010, 192).

Dalam perspektif manajemen, paradigma kepemimpinan yang sekarang ini telah mengalami suatu perubahan, dalam melakukan reformasi dan perubahan demokratis telah terlihat secara jelas dalam kehidupan ini. Artinya, setiap pemimpin dituntut untuk selalu menyesuaikan pola perilaku kepemimpinannya dengan situasi dan kondisi yang selalu berubah.

Pendekatan gaya kepemimpinan lebih menekankan pada perilaku seorangi pemimpin, baikitu perilaku kerja maupun perilakui hubungan. Perilaku kerja memfasilitasi tercapainya tujuan dengan membantu anggota kelompok mencapai tujuannya, sedangkan perilaku hubungan membantu bawahan untuk tetap merasa nyaman, baik dengan dirinya, dengan orang lain, maupun dengan situasi tempat mereka berada. Gaya kepemimpinan ini bertujuan menjelaskan bagaimana pemimpin dapat mengkombinasikan kedua jenis perilaku ini (kerja dan hubungan) guna memengaruhi bawahan dalam upayanya mencapai tujuan madrasah (Poppy Ruliana, 2016: 137138). Penelitian lainnya menunjukkan bahwa ada hubungan langsung antara gaya kepemimpinan kepala madrasah dengan kinerja madrasah. Hal ini juga mengindikasikan bahwa efektif gaya kepemimpinan kepala madrasah, semakin baik pula kinerja madrasah tersebut (Abdul Kadim Masaong, 2011: 155).

Kepala madrasah pada dasarnya dapat dengan mudah untuk meningkatkan komponen-komponen yang ada di dalam madrasah jika gaya kepemimpinan yang digunakan sudah tepat dan sesuai dengan kondisi yang dihadapi. Intinya adalah kepala madrasah 
harus berusaha agar dapat memberikan motivasi kepada warga madrasah dengan berbagai gaya, situasi kepemimpinan, serta berusaha untuk dapat menciptakan suasana kerja madrasah yang memungkinkan seluruh warga madrasah dapat termotivasi untuk bekerja sesuai dengan tujuan pendidikan yang diharapkan, maka dari itu kinerja kepala madrasah hendaknya selalu ditingkatkan. Terdapat berbagai penelitian terkait dengan gaya kepemimpinan kepala madrasah yang dapat meningkatkan kinerja guru lembaga pendidikan, misalnya adalah penelitian Sri Setiyati (2014: 200) tentang pengaruh kepemimpinan kepala madrasah, motivasi kerja, dan budaya madrasah terhadap kinerja guru di SMK Negeri 1 Gunung Kidul. Hasil penelitiannya membuktikan bahwa ketiga variabel independen tersebut berpengaruh positif dan signifikan terhadap kinerja guru di SMK Negeri 1 Gunung Kidul dengan nilai koefisien korelasi 0,288. Penelitian Edianto (2017: xii) tentang hubungan antara manajemen kepala madrasah dan iklim madrasah dengan efektivitas kinerja guru di SD Negeri Bontokamase Kecamatan Somba Opu Kabupaten Gowa. Hasil penelitiannya menunjukkan bahwa terdapat korelasi positif dan signifikan manajemen kepala madrasah dan iklim madrasah dengan efektivitas kinerja guru dengan nilai koefisien korelasi 0,445.

Madrasah Aliyah Pondok Pesantren Al-Ikhlas Ujung Kecamatan Dua Bocco'e Kabupaten Bone menurut pengamatan sementara (observasi awal) masih ada beberapa guru yang tidak membuat (RPP) sebelum memulai pembelajaran serta jarang membuat program kerja tahunan. Hal ini diduga ada hubungannya dengan gaya kepemimpinan kepala madrasah. Mencermati fenomena tersebut maka kiranya perlu lebih lanjut untuk meneliti tentang hubungan gaya kepemimpinan kepala madrasah dengan kinerja gurudi Madrasah Aliyah Pondok Pesantren Al-
Ikhlas Ujung Kecamatan Dua Bocco'e Kabupaten Bone.

Penelitian ini lebih mengfokuskan pada realitas gaya kepemimpinan kepala madrasah, realitas kinerja guru, serta korelasinya antara gaya kepemimpinan kepala madrasah dengan kinerja guru di Madrasah Aliyah Pondok Pesantren AlIkhlas Ujung Kecamatan Dua Bocco'e Kabupaten Bone. Adapun tujuan penelitian ini, yaitu untuk mendeskripsikan realitas gaya kepemimpinan kepala madrasah, mendeskripsikan kinerja guru, dan menguji tingkat korelasi antara gaya kepemimpinan kepala madrasah dengan kinerja guru di Madrasah Aliyah Pondok Pesantren Al-Ikhlas Ujung Kecamatan Dua Bocco'e Kabupaten Bone.

\section{LANDASAN TEORETIS}

\section{Gaya Kepemimpinan Kepala Madrasah}

Konsep seorang pemimpin pendidikan tentang kepemimpinan dari kekuasaan yang mengproyeksikan diri dalam bentuk sikap memimpin, tingkah laku, dan sifat kegiatan pemimpin yang dikembangkan dalam lembaga pendidikannya akan mempengaruhi situasi kerja, semangat kerja anggota, sifat hubungan kemanusiaan di antara sesamanya, dan akan mempengaruhi kualitas hasil kerja yang mungkin dapat dicapai oleh lembaga pendidikan tersebut (Abdul Azis Wahab, 2011: 34) Oleh karena itu, dalami melaksanakan fungsi kepemimpinani maka akan berlangsung aktivitas kepemimpinan. Apabila aktivitas tersebut dipilah-pilah, maka akan terlihat gaya kepemimpinan dengan pola masingmasing. Gaya kepemimpinan tersebut merupakan pondasi dasar dari tipe kepemimpinan yang ditonjolkan oleh pemimpin.

Kepala madrasah dalam menjalankan tugas sehari-hari tidak terlepas dari gaya kepemimpinan yang diterapkan. Oleh karena itu, sebagai 
pemimpin pendidikan perlu memahami tentang keefektifan kepemimpinan. Sehingga salah satu tinjauan tentang gaya kepemimpinan yang dapat di terapkan di madrasah adalah gaya kepemimpinan yang berorientasi padai tugas dan gaya kepemimpinan yang berorientasi pada manusia. Gaya kepemimpinan yang berorientasi pada tugas adalah gaya kepemimpinan yang lebih menaruh perhatian pada struktur tugas, penyusunan rencana kerja, penetapan polaorganisasi, metode kerja dan prosedur pencapaian tujuan. Sedangkan gaya kepemimpinan yangi berorientasi pada hubungan manusia adalah kepemimpinan yang lebih menaruh perhatian pada kepercayaan, kehangatan antara pemimpin dan anggota (Abdul Kadim Masaong, 2011: 163).

Berdasarkan uraian tentang dua perilaku seorang pemimpin mengandung makna bahwa seorangi pemimpin dapat membantu organisasi mencapai tujuannya lewat duaperilaku, yaitu perhatian pada tugas ataupun pada halhal yang telah direncanakan untuk diselesaikan oleh organisasi (perilaku tugas), serta perhatian kepada orangorang dan unsur-unsur organisasi yang memengaruhi mereka (perilaku hubungan).

Suatu madrasah akan berhasil ataui gagal sebagian besar ditentukan oleh kepemimpinan lembaga itu. Kepemimpinan yangi baik adalah suatu kepemimpinan yang menunjukkan kombinasi antara hubungan pemimpin dengan anggota yang baik dengan tugastugas yang teratur dan terstruktur. Pada dasarnya kepemimpinan yang efektif dapat diklasifikasikan menjadi sebagai berikut; (Syaiful Sagala, 2008: 152).

a. Gaya memberitahu ini diterapkan jika anak buah dalam tingkat kematangan rendah, dan memerlukan petunjuk serta pengawasan yang jelas. Gaya ini sering disebut sebagai mendikte karena pemimpin dituntut untuk mengatakan apa, bagaimana, kapan, dan di mana tugas dilakukan. Gaya ini menekankan pada tugas, sedangkan hubungan hanya dilakukan sekedarnya saja.

b. Gaya menjual ini diterapkan apabila kondisi para bawahan dalam taraf rendah sampa moderat. Mereka telahi memiliki kemampuan untuk melaksanakan tugas, tetapi belum didukung oleh kemampuan yang memadai. Gaya ini biasanya disebut sebagai gaya menjual, karena pemimpin selalu memberikan petunjuk yang banyak. Dalam tingkat kematangan bawahan seperti ini diperlukan tugas sertai hubungan yang tinggi agar dapat memelihara dan meningkatkan kemauan yang telah dimiliki.

c. Gaya melibatkan diri ini diterapkan apabila tingkat kematangan bawahan berapa pada taraf kematangan moderat sampai tinggi. Mereka mempunyai kemampuan, tetapi kurang memiliki kemauan kerja dan kepercayaan diri. Gaya ini sering disebut sebaga mengikuti sertakan diri, karena pemimpini dan bawahan bersama-sama berperan di dalam proses pengambilan keputusan. Dalam kematangan seperti ini, upaya tugas tidak diperlukan, namun upaya hubungan perlu ditingkatkan dengan membuka komunikasi dua arah.

d. Gaya mendelegasikan ini diterapkan jika kemampuan dan kemauan para bawahan telah tinggi. Gaya ini biasanya disebut sebagai gaya mendelegasikan, karena bawahan dibiarkan melaksanakan kegiatan sendiri, melalui pengawasan umum. Hal ini biasanya dilakukan jika bawahan tingkat kedewasaannya yang tinggi. Dalam tingkat kematangan seperti ini hanya perlukan sekedarnya saja, demikian pula dengan hubungan kepada bawahan (E. Mulyasana, 2015: 116). Sehingga dapat dipahami bahwa 
dalam gaya kepemimpinan yang tersebut pada dasarnya menjelaskan tentang tiga dimensi kepemimpinan antara lain seperti, perilaku tugas, perilaku hubungan dan yang terakhir adalah kematangan.

Untuk

menentukan

gaya

kepemimpinan yangi cocok pada situasi dan kondisi yang dihadapi, seorang manajer pertama kali harus menetapkan taraf kematangan individual atau kelompoki dalami hubungannyai dengan tugasi spesifiki yangi dimintaii pemimpin untukmerekai selesaikan. Oleh karena itu, hendaknya pemimpin dalam hal ini kepala madrasah jika kematangan bawahan rendah harus memakai gaya yangi banyak mengarahkani kepada bawahannya. Meskipun perilaku hubungan rendah tidaklah berarti bahwa pemimpin tidak bersahabat atau tidak dapat bersifat informal terhadap madrasah yang dikelola, tetapi ketika memberikan pengawasan kepada madrasah tersebut perlu lebih banyak waktu untuk mengarahkan mengena apa yang akan dilakukan, bagaimana, dan dimana dibandingkan dengan memberikan dukungan dan penguatan yangi bersifat sosial emosional. Apabila dengan cara tersebut tampak kematangan para bawahan meningkat, segera perilaku hubungan diperbesar, dengan demikian, titik berati gaya kepemimpinan akan bergerak dari gaya satu (tugas tinggi dani hubungan rendah) ke gaya dua (tugas tinggi dan hubungan tinggi) (B. Siswanto, 2010: 168-169).

Seorang pemimpin yang baik mampui mengembangkan kompetens dan komiten dari pengikutnya sehingga mereka termotivasi diri sendiri dari pada bergantung padaorang lain untuk diarahkan atau dibimbing. Menurut Hersey dalam Ahmad Susanto mengatakan bahwa tingginya kinerja pemimpin menciptakan harapan yang realitas akan tingginya kinerja pengikut. Sebaliknya jika rendahnya harapan pemimpin mengakibatkan rendahnya kinerja pengikut, sehingga untuk meningkatkan dan mengembangkan kompetensi dan komitmen para pengikutnya pemimpin harus mampu mengkombinasikan dari empat gaya kepemimpinan yang efektif tersebut (Ahmad Susanto, 2016: 86).

Pemimpin yang berhasil haruslah memilikii sifat kepribadian seperti stamina fisik, kecerdasan dan kearifan dalam bertindak, kemauan menerima tanggung jawab, kompeten dalam menjalankan tugas, memahami kebutuhan pengikutnya, memiliki keterampilan dalami berhubungan dengan orang lain, kebutuhan untuk berprestasi, mampu memotivasi dan memberikan semangat, mampu memecahkan masalah, meyakinkan, memiliki kapasitas untuk menang, memiliki kapasitas untuk mengelola, memutuskan, menentukan atau memiliki fleksibilitas (Veithzal Rivai Zainal, dkk., 2013). Artinya pemimpin yang dapat menjadi teladan yang baik untuk menuju perubahan dalam suatu organisasi atau madrasah, sebagaimana firman Allah SWT. dalam Q.S. Al-Nahl ayat 16 : 120.

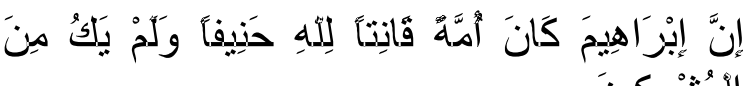
المُشْْر كِينَ.

"Sesungguhnya Ibrahim adalah seorang imam yang dapati dijadikan teladan lag patuh kepadai Allah dani hanif. dan sekali-kali bukanlah dia termasuki orangorang yang mempersekutukani (Tuhan). (Kementerian Agama RI, 2014: 504)."

Berdasarkan ayat tersebut dapat dipahami bahwa Allah SWT. telah menjelaskan kepada semua manusia khususnya umat Islam tentang pemimpin yang berhasil memiliki karakteristik sifat dan keterampilan tertentu. Cirinya antara lain dapat beradaptasi dengan situasi dan kondisi, peka terhadap lingkungan sosial, berorientasi pada hasil, tegas, dapat bekerja sama, meyakinkan, mandiri, dan mampu memengaruhi orang lain. 
Sedangkan keterampilan yang harus dimiliki oleh pemimpin antara lain cerdas, terampil secara konseptual, kreatif, memiliki pengetahuan terhadap tugas kelompok, mampu mengorganisir, mampu memengaruhi, meyakinkan dan memiliki keterampilan sosial.

\section{Kinerja Guru}

Kinerja guru merupakan kemampuan seorangi guru dalam melaksanakan tugas pembelajaran di madrasah dan bertanggung jawab atas pesertai didik di bawah bimbingannya dengan meningkatkan prestasi belajar peserta didik. Oleh karena itu, kinerja guru dapat diartikan sebagai suatu kondisi yang menunjukkan kemampuan seorang guru dalam menjalankan tugasnya di madrasah serta menggambarkan adanya suatu perbuatan yangi ditampilkan guru dalam melakukan aktivitas pembelajaran, sebagaimana Allah SWT. berfirman dalam Q.S. Al-Ahqaf ayat 19 , yaitu:

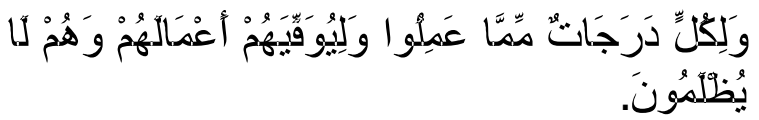

"Dan setiap orang memperoleh tingkatan yang sesuai dengan apa yang telah mereka kerjakan, dan agar Allah mencukupkan balasan perbuatan mereka, dan mereka tidak dirugikan" (Kementerian Agama RI, 2014: 504).

Mereka yang taat dan durhaka itu akan memperoleh ganjaran yang berbeda-beda di surga dan neraka agar menjadi jelas buat semua keadilan Allah balasan dalam saat yang sama pun, bahkan yang taat diberi ganjaran yang berlipat ganda (M. Quraish Shihab, 2009: 412-413). Berdasarkan ayat tersebut dapat dipahami bahwa Allah swt. telah menjelaskan kepada semua manusia khususnya umat Islam dapat pahami bahwa setiap orang mengerjakan sesuatu akan mendapatkan apa yang mereka dapatkan, artinya apa yang ditanam itulah yang akan didapat. Setiap orang akan mendapatkan balasan atas apa yang mereka kerjakan.

Kinerja guru akan menjadi optimal bila diintegrasikan dengan komponen madrasah, baik kepemimpinan kepala madrasah, budaya madrasah, motivasi kerja guru, dan karyawan maupun anak didik. Adapun Faktor yang dapat mempengaruhi kinerja guru dalam melaksanakan tugas pokoknya, yaitu kepemimpinan, fasilitas kerja, harapan, dan kepercayaan personalia madrasah. Dengani demikian, tampak bahwa kepemimpinan kepala madrasah dan fasilitas kerja akan ikut menentukan baik buruknya kinerja guru. Dengan kata lain, kepemimpinan kepala madrasah berpengaruh terhadap kinerja guru (Ester Malik, Kamal Bustomi, 2011: 11). Oleh karena itu, salah satu upaya dalam meningkatkan kinerja guru adalah dengan memberikan motivasi terhadap guru yang berupa penghargaan, baik berupa materi maupun nonmateri sebagai bentuk apresiasi kepala madrasah terhadap hasil kerja guru. Sehingga ini akan menjadi sebuah dorongan guru untuk bekerja secara profesional dengan meningkatkan kompetensinya.

Kompetensi guru di Indonesia telah dikembangkan pula oleh Proyek dan Kebudayaan Guru (P3G) Departemen Pendidikan dan Kebudayaan (Ali Mudlofir, 2014: 74-75). Untuk keperluan analisis tugas sebagai pengajar, kompetensi kinerja profesi keguruan dalam penampilan aktual dalam proses pembelajaran minimal memiliki empat kemampuan, yakni kemampuan:

a. Merencanakan proses pembelajaran

b. Melaksanakan, dan mengelola proses pembelajaran

c. Menilai kemajuan pembelajaran

d. Menguasaii bahani pelajaran.

Kinerja guru dapat terlihat jelas melalui prestasi peserta didik. Kinerja guru yangi baik akan menghasilkan prestasi belajar peserta didik yang baik. 
Menurut Murgantroyd dan Morgani dalam Supardi mengemukakan terdapat indikator kinerja guru akan tampak dalam hal kepuasan peserta didik dan orangtua peserta didik, prestasi belajar peserta didik, perilaku sosial dan kehadiran guru. Dengan demikian, jelaslah bahwa menilai dan memahami kinerja guru tidak terlepas daripeserta didik sebaga subjek didik dan tingkat prestasi belajar yang dicapai peserta didik merupakan gambaran kinerja guru sebagai perencanaan dan pengelola pembelajaran atau administrator kelas (Supardi, 2013: 105).

Peningkatan kinerja guru dapat tercapai apabila kepala madarsah sebagai pemimpin menggeser fokus tanggung jawab dari operasional manajerial kepada pengajar. Hal tersebut senada yang dikatakan oleh Chang dalam bukunya Ahmad Susanto (2016: 86) bahwa guru merupakan salah satu faktor penentu tinggi rendahnya mutu hasil pendidikan.

Keberhasilan penyelenggaraan pendidikan sangat ditentukan oleh sejauh mana kesiapan guru dalam mempersiapkan peserta didiknya melalui kegiatan pembelajaran. Namun demikian, posisi strategi guru untuki meningkatkan mutui hasil pendidikan sangat dipengaruhi oleh kemampuan profesional mengajarnya. Kepala madrasah sebagai pemimpin dalam meningkatkan mutu pembelajaran di madrasahnya akan mencurahkan sebagaian besarwaktunya bagi pengembangan guru. Jika guru telah mendapatkan perhatian yang lebih dalam kegiatan pengajaran yang dilakukannya, maka hal itu akan meningkatkan kinerja, khususnya kinerja dalam mengajar (Ahmad Susanto, 2016: 89).

\section{Hipotesis}

Hipotesis merupakan suatu jawaban sementara terhadapa rumusan masalah dalam penelitian yang masih berdasar pada teori, belum didasarkan pada fakta empiris. Hipotesis yang digunakan meruapakan hipotesis asosiatif yang menanyakan hubungan antara dua variabel atau lebih, yaitu "Terdapat korelasi antara gaya kepemimpinan kepala madrasah dengan kinerja guru di Madrasah Aliyah Pondok Pesantren AlIkhlas Ujung Kecamatan Dua Bocco'e Kabupaten Bone."

\section{METODOLOGI PENELITIAN}

Jenis penelitian ini adalah penelitian kuantitatif dengan metode ex post facto. Penelitian korelasi adalah suatu penelitian yang melibatkan tindakan pengumpulan data untuk menentukan hubungan dan tingkat hubungan antara dua variabel atau lebih (Sukardi, 2013: 166).Penelitian dilaksanakan di Madrasah Aliyah Pondok Pesantren Al-Ikhlas Ujung Kecamatan Dua Bocco'e Kabupaten Bone. Penelitian ini berlokasikan di Jln. Pendidikan No. 2 Desa Ujung Kecamatan Dua Bocco'e Kabupaten Bone Provinsi Sulawesi Selatan.

Pendekatan penelitian ini dilihat dari perspektif metodologis adalah pendekatan positivistic (Sitti Mania, 2013: 45). Pendekatan ini merupakan metode ilmiah karena telah memenuhi kaidahkaidah ilmiah yaitu konkrit/empiris, objektif, terukur, rasional, dan sistematis (Sugiyono, 2016: 7). Penelitian ini menggunakan pendekatan positivistik dengan pendekatan kuantitatif. Pendekatan keilmuan dalam penelitian ini adalah pendekatan sosiologis dan psikologis. Pendekatan sosiologis sangat diperlukan dalam penelitian ini sebab peneliti akan menggunakan angket sebagai alat untuk mendapatkan data yang perlukan. Dalam angket tersebut peneliti telah menuangkan beberapa aspek sosial karena ada keterkaitannya dengan variabel-variabel penelitian ini. Pendekatan psikologi ini juga akan membantu peneliti untuk mendapatkan data yang diperlukan dalam penelitian ini sebab dalam angket yang akan diberikan kepada guru sebagai responden juga akan dituangkan beberapa aspek psikologi 
atau mengenai kejiwaan, karena psikologi ini juga memiliki hubungan dengan variabel-variabel dalam penelitian ini.

Adapun yang menjadi populasi penelitian ini, yaitu seluruh guru di Madrasah Aliyah Pondok Pesantren AlIkhlas Ujung Kecamatan Dua Bocco'e Kabupaten Bone sebanyak 28 orang guru yang terdiri dari 18 orang laki-laki dan 10 orang perempuan. Adapun teknik dalam penentuan sampel penelitian ini dilakukan dengan menggunakan sampel jenuh, yaitu teknik penentuan sampel bila semua anggota populasi digunakan sebagai sampel. Hal ini dilakukan bila jumlah populasi relatif kecil, kurang dari 30 orang, atau penelitian yang ingin membuat generalisasi dengan kesalahan yang sangat kecil(Sugiyono, 2016: 85). Oleh karena itu, sampel dalam penelitian ini adalah semua guru di Madrasah Aliyah Pondok Pesantren Al-Ikhlas Ujung Kecamatan Dua Bocco'e Kabupaten Bone yang berjumlah 28 orang.

Teknik pengumpulan data dalam penelitian merupakan langkah yang sangat strategis, sebab tujuan utama dalam melakukan penelitian adalah memperoleh data. Sehingga teknik pengumpulan yang digunakan dalam penelitian ini adalah berupa angket. Angket disusun berdasarkan indikator dari setiap dimensi variabel penelitian ini kemudian diedarkan kepada seluruh guru di Madrasah Aliyah Pondok Pesantren AlIkhlas Ujung Kecamatan Dua Bocco'e Kabupaten Bone. Teknik pengelolaan dan analisis data yang digunakan dalam penelitian ini adalah teknik scoring, penyajian data dalam bentuk distribusi frekuensi dan perhitungan rata-rata mean score yang diinterpretasikan ke dalam kategori yang telah ditentukan. Adapun pengujian hipotesis yang dilakukan dengan menggunakan analisis korelasi product moment yang hasilnya dinterpretasikan ke dalam nilai koefisien korelasi yang telah ditentukan

\section{HASIL PENELITIAN}

\section{Realitas Gaya Kepemimpinan Kepala Madrasah di Madrasah Aliyah Pondok Pesantren Al-Ikhlas Ujung Kecamatan Dua Bocco'e Kabupaten Bone}

Rata-rata tanggapan responden diinterpretasikan pada pedoman konversi nilai dengan ketentuan: Jumlah pernyataan $=20$; jumlah alternatif jawaban $=5$ (berdasarkan skala Likert); skor maksimal setiap item $=5$ sehingga skor kriterium (ideal) $=20 \times 5=100$ dan skor minimum setiap item $=1$ sehingga skor terendah yang mungkin diperoleh $=$ $20 \times 1=20$. Dengan demikian, range $=$ $100-20=80$ dan interval kelas $=80 / 5=$ 16 sehingga dapat dibuat tabel seperti berikut ini:

Tabel 1 Interpretasi Kategori Gaya Kepemimpinan Kepala Madrasah

\begin{tabular}{|c|c|c|c|}
\hline Interval & Kategori & Frekuensi & Persentase \\
\hline $20-36$ & Sangat tidak baik & 0 & $0 \%$ \\
\hline $37-52$ & Tidak baik & 0 & $0 \%$ \\
\hline $53-68$ & Sedang & 1 & $3,57 \%$ \\
\hline $\mathbf{6 9}-\mathbf{8 4}$ & Baik & 20 & $71,43 \%$ \\
\hline $85-100$ & Sangat baik & 7 & $25 \%$ \\
\hline Jumlah & - & $\mathbf{2 8}$ & $\mathbf{1 0 0 \%}$ \\
\hline
\end{tabular}

Berdasarkan tabel tersebut dapat diketahui bahwa rata-rata tanggapan dari
28 responden yang sebesar 82,25 berada pada interval 69 - 84 yang menandakan bahwa gaya kepemimpinan kepala 
madrasah termasuk dalam kategori baik dengan jumlah frekuensi sebanyak 20 orang dan persentase sebesar $71,43 \%$.

Jumlah skor total (sum) juga dapat diinterpretasikan ke dalam garis kontinum dengan ketentuan: Jumlah item pernyataan $=20$, jumlah alternatif jawaban $=5$ dan jumlah responden $=28$ sehingga jumlah skor total kriterium (ideal) $=20 \times 5 \times 28=2.800$ dan jumlah skor total terendah yang mungkin diperoleh $=20 \times 1 \times 28=560$. Ketentuan tersebut dapat digambarkan pada garis kontinum berikut:

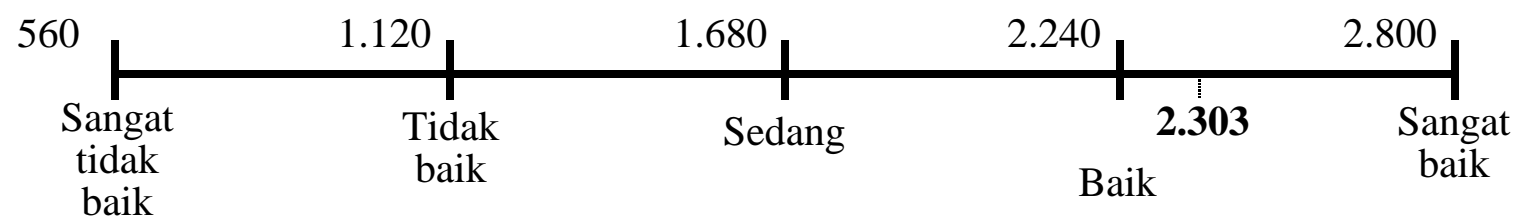

Gambar 1 Interpretasi Kategori Gaya Kepemimpinan Kepala Madrasah Berdasarkan Garis Kontinum

Berdasarkan garis kontinum tersebut dapat diketahui bahwa jumlah skor total perolehan yang sebesar 2.303 berada pada daerah baik. Dengan demikian, gaya kepemimpinan kepala madrasah $=2.303 / 2800=0,8225$ atau $82,25 \%$.

2. Realitas Kinerja Guru di Madrasah Aliyah Pondok Pesantren Al-Ikhlas Ujung Kecamatan Dua Bocco'e Kabupaten Bone

Rata-rata tanggapan responden diinterpretasikan pada pedoman konversi nilai dengan ketentuan: Jumlah pernyataan $=20$; jumlah alternatif jawaban $=5$ (berdasarkan skala Likert); skor maksimal setiap item $=5$ sehingga skor kriterium (ideal) $=20 \times 5=100$ dan skor minimum setiap item $=1$ sehingga skor terendah yang mungkin diperoleh $=$ $20 \times 1=20$. Dengan demikian, range $=$ $100-20=80$ dan interval kelas $=80 / 5=$ 16 sehingga dapat dibuat tabel konversi nilai sebagai berikut:

Tabel 2 Interpretasi Kategori Kinerja Guru

\begin{tabular}{|c|c|c|c|}
\hline Interval & Kategori & Frekuensi & Persentase \\
\hline $20-36$ & Sangat rendah & 0 & $0 \%$ \\
\hline $37-52$ & Rendah & 0 & $0 \%$ \\
\hline $53-68$ & Sedang & 0 & $0 \%$ \\
\hline $\mathbf{6 9}-\mathbf{8 4}$ & Tinggi & 19 & $67,86 \%$ \\
\hline $85-100$ & Sangat tinggi & 9 & $32,14 \%$ \\
\hline Jumlah & - & $\mathbf{2 8}$ & $\mathbf{1 0 0 \%}$ \\
\hline
\end{tabular}

Berdasarkan tabel tersebut dapat diketahui bahwa rata-rata tanggapan dari 28 responden yang sebesar 84,21 berada pada interval 69 - 84 yang menandakan bahwa kinerja guru termasuk dalam kategori tinggi dengan jumlah frekuensi sebanyak 19 orang dan persentase sebesar $67,86 \%$.
Jumlah skor total (sum) iklim madrasah juga dapat diinterpretasikan ke dalam garis kontinum dengan ketentuan: Jumlah item pernyataan $=20$, jumlah alternatif jawaban $=5$ dan jumlah responden $=28$ sehingga jumlah skor total kriterium (ideal) $=20 \times 5 \times 28=$ 2.800 dan jumlah skor total terendah 
yang mungkin diperoleh $=20 \times 1 \times 28=$ digambarkan pada garis kontinum 560. Ketentuan tersebut dapat berikut:

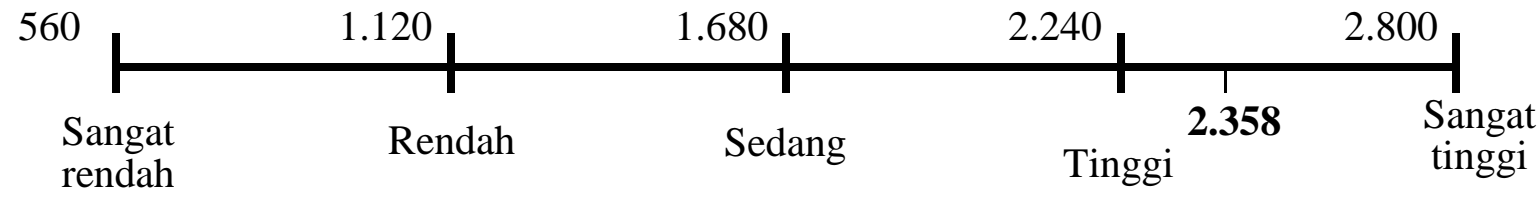

Gambar 2 Interpretasi Kategori Kinerja Guru Berdasarkan Garis Kontinum 
Berdasarkan garis kontinum tersebut dapat diketahui bahwa jumlah skor total perolehan yang sebesar 2.358 berada pada daerah tinggi sehingga kinerja guru termasuk kondusif karena mendekati kriteria yang ditetapkan. Dengan demikian, kinerja guru $=2.358 /$ $2.800=0,8421$ atau $84,21 \%$.

\section{Korelasi Gaya Kepemimpinan Kepala Madrasah dengan Kinerja Guru di Madrasah Aliyah Pondok Pesantren Al-Ikhlas Ujung Kec. Dua Bocco'e Kab. Bone}

Hubungan dan tingkat hubungan antara variabel $\mathrm{X}$ (gaya kepemimpinan kepala madrasah) dengan $Y$ (kinerja guru) di Madrasah Aliyah Pondok Pesantren Al-Ikhlas Ujung Kecamatan Dua Bocco'e Kabupaten Bone dapat diketahui dengan menggunakan analisis korelasi product moment.Analisis korelasi antara gaya kepemimpinan kepala madrasah $\left(\mathrm{X}_{1}\right)$ dengan kinerja guru $(\mathrm{Y})$ dilakukan dengan menggunakan rumus korelasi product moment berikut:

$$
\begin{aligned}
r_{x_{1} y} & =\frac{N \sum X_{1} Y-\left(\sum X_{1}\right)\left(\sum Y\right)}{\sqrt{\left[N \sum X_{1}^{2}-\left(\sum X_{1}\right)^{2}\right]\left[N \sum Y^{2}-\left(\sum Y\right)^{2}\right]}} \\
& \text { Maka: } \\
r_{x_{1} y} & =\frac{28 \times 194.346-(2.303)(2.358)}{\sqrt{\left[28 \times 190.689-(2.303)^{2}\right]\left[28 \times 200.062-(2.358)^{2}\right]}} \\
& =\frac{5.441 .688-5.430 .474}{\sqrt{(5.339 .292-5.303 .809)(5.601 .736-5.560 .164)}} \\
& =\frac{11.214}{\sqrt{(35.483)(41.572)}} \\
& =\frac{11.214}{\sqrt{1.475 .099 .276}} \\
& =\frac{11.214}{38.407,021} \\
& =0,292
\end{aligned}
$$

Berdasarkan perhitungan tersebut, diperoleh nilai korelasi product moment antara gaya kepemimpinan kepala madrasah dengan kinerja guru sebesar 0,292 .

\section{PEMBAHASAN}

\section{Realitas Gaya Kepemimpinan Kepala Madrasah di Madrasah}

\section{Aliyah Pondok Pesantren Al-Ikhlas Ujung Ke. Dua Bocco'e Kab. Bone \\ Hasil \\ analisis \\ deskriptif}

menunjukkan bahwa rata-rata tanggapan dari 28 responden terkait gaya kepemimpinan kepala madrasah di Madrasah Aliyah Pondok Pesantren AlIkhlas Ujung Kecamatan Dua Bocco'e Kabupaten Bone sebesar 82,25. Berdasarkan konversi nilai yang dilakukan, mean score atau rata-rata tanggapan tersebut berada pada interval 69-84 yang mengindikasikan bahwa gaya kepemimpinan kepala madrasah termasuk pada kategori baik dengan jumlah frekuensi sebanyak 20 orang dan persentase sebesar 71,43\%, lebih jelasnya dapat dilihat pada tabel 1 .

Hasil analisis deskriptif juga menunjukkan bahwa jumlah skor total perolehan $=2.303$. Hasil interpretasi dengan menggunakan garis kontinum menunjukkan bahwa gaya kepemimpinan kepala madrasah di Madrasah Aliyah Pondok Pesantren Al-Ikhlas Ujung Kecamatan Dua Bocco'e Kabupaten Bone berada pada daerah baik karena nilai jumlah skor total $=2.303$ mendekati kriteria yang ditetapkan. Nilai persentase gaya kepemimpinan kepala madrasah berdasarkan hasil analisis $=2.303 / 2.800$ $=0,8225$, lebih jelas dapat dilihat pada gambar 1 . Dengan demikian, realitas gaya kepemimpinan kepala madrasah di Madrasah Aliyah Pondok Pesantren AlIkhlas Ujung Kecamatan Dua Bocco'e Kabupaten Bone 82,25\%.

Berdasarkan hasil penelitian yang menunjukkan bahwa gaya kepemimpinan kepala madrasah di Madrasah Aliyah Pondok Pesantren Al-Ikhlas Ujung Bone dapat dikatan baik berdasarkan hasil dari pengisian angket oleh guru, dari tanggapan mereka rata mengganggap bahwa gaya kepemimpin kepala madarsanya itu sudah baik, sehingga sesuai dengan apa yang telah dikemukakan oleh Abdul Kadim Masaong dan Arfan A. Timole $(2011,161)$ yang 
mengatakan bahwa kepemimpinan yang dilakukan oleh kepala madrasah dalam rangkan menggerakkan warga madrasah agar berbuat sesuatu untuk mewujudkan program kerja yang telah dirumuskan, sehingga keberhasilan kepala madrasah tergantung dari bagaimana kemampuan dasar pemimpinnya dalam rangka melaksanakan fungsinya sebagai kepemimpinan yang baik. Artinya kepala madrasah Madrasah Aliyah Pondok Pesantren Al-Ikhlas Ujung Bone telah menjalankan fungsinya sebagai mestinya sehingga rata-rata tanggapan dari responden yang menganggap bahwa gaya kepemimpinan yang terapkan leh kepala madrasah sudah baik dan benar.

Berdasarkan dari hasil analisis angket yang menujukkan bahwa gaya kepemimpina kepala madrasah di Madrasah Aliyah Pondok Pesantren AlIkhlas Ujung Kecamatan Dua Bocco'e beada pada kategori baik, artinya dari sekian jumlah pernyataan angket tersebut sekitar 20 dari 2 dimensi yaitu, perilaku kerja dan perilaku hubungan menunjukkan bahwa dimensi perilaku kerja lebih tinggi sekornya dibandingkan dengan dimensi perilaku hubungan, sehingga gaya kepemimpinan kepala madrasah tidak dapat mencapi kategori sangat baik, karena masih ada beberapa indikator belum terpenuhi secara sempurna. Dari kedua dimensi gaya kepemimpinan kepala madrasah dari hasil di lapangan menunjukka masingmasing dimensi masih belum optimal, karena jawaban dari 28 responden terkait dimensi perilaku hubungan dari indikator seperti "kepala madrasah tidak pernah konflik dengan warga madrasah" yang memiliki skor yang sedikit rendah, sedangkan perilaku kerja dari indikator seperti "kepala madrasah tidak termotivasi untuk membuat orang lain merasa senang kepadanya" juga memiliki skor yang sedikit rendah, meskipun masing-masing memiliki kekurangan akan tetapi perilaku kerja sedikit tinggi dari pada perilaku hubungan. Sehingga boleh jadi ini yang menjadi dasar kenapa gaya kepemimpinan kepala madraah di Madrasah Aliyah Pondok Pesantren AlIkhlas Ujung Kecamatan Dua Bocco'e berada pada kategori baik, bukan pada kategori sangat baik, sedang, tidak baik, dan sangat tidak baik, karena masih ada sedikit indikator gaya kepemimpinan kepala madrasah belum maksimal diterapkan.

\section{Realitas Kinerja Guru di Madrasah Aliyah Pondok Pesantren Al-Ikhlas Ujung Kec. Dua Bocco'e Kab. Bone}

Hasil analisis deskriptif menunjukkan bahwa rata-rata tanggapan dari 28 responden terkait kinerja guru di Madrasah Aliyah Pondok Pesantren AlIkhlas Ujung Kecamatan Dua Bocco'e Kabupaten Bone sebesar 84,21. Berdasarkankonversi nilai yang dilakukan, mean score atau rata-rata tanggapan responden tersebut berada pada angka interval 69-84 yang mengindikasikan bahwa kinerja guru termasuk pada kategori tinggi dengan jumlah frekuensi sebanyak 19 orang dan persentase sebesar 67,86\%, lebih jelasnya dapat dilihat pada tabel 2 .

Hasil analisis deskriptif juga menunjukkan bahwa jumlah skor total perolehan $=2.358$. Hasil interpretasi dengan menggunakan garis kontinum menunjukkan bahwa kinerja guru di Madrasah Aliyah Pondok Pesantren AlIkhlas Ujung Kecamatan Dua Bocco'e Kabupaten Bone berada pada daerah tinggi karena nilai jumlah skor total = 2.358 mendekati kriteria yang ditetapkan. Nilai persentase kinerja guru berdasarkan hasil analisis $=2.358 / 2.800$ $=0,8421$, lebih jelasnya dapat dilihat pada tabel 2. Dengan demikian, realitas kinerja guru di Madrasah Aliyah Pondok Pesantren Al-Ikhlas Ujung Kecamatan Dua Bocco'e Kabupaten Bone 84,21\% dari kriteria yang ditetapkan.

Berdasarkan dari hasil penelitian yang menujukkan bahwa kinerja guru di 
Madrasah Aliyah Pondok Pesantren AlIkhlas Ujung Bone dapat dikategorikan tinggi, sehingga hal ini sesuai dengan pendapat Abd. Wahab dan Umiarso (2011: 122) yang mengatakan bahwa indikator kinerja guru itu sendiri dapat dilihat dari bagaimana seorang guru memiliki kemampuan dalam merencanakan dan mempersiapakan pembelajaran, penguasaan materi ajar, penguasaan terhadap metode yang akan digunakan, pemberian tugas-tugas kepada peserta didik, kemampuan dalam mengelolah kelas dengan baik dan benar, serta kemampuan dalam melakuakn sebuah penilaian dan evaluasi dari proses pembelajaran yang dilakukannya. Artinya kinerja guru yang tinggi akan terlihat jelas bila mana indikator-indikator tersebut dapt terpenuhi.

Dalam bukunya Ahmad Susantu (2016: 89) yang menjelaskan bahwa kepala madrasah sebagai pemimpin dalam hal meningkatkan mutu pembelajaran akan memberikan perhatian besar dalam pengembanagan guru. Jika guru telah mendapatkan perhatian besar dalam hal kegiatan pembelajaran, maka hal tersebut akan memicu pada peningkatan kinerja, khususnya kinerja guru dalam pembelajaran. Sehingga tidak heran jika kinerja guru di Madrasah Aliyah Pondok Pesantren Al-Ikhlas Ujung Bone berada pada kategori tinggi, sehingga inilah yang menjadi dasar kenapa kinerja guru di madrasah tersebut tingga, karena kepemimpinan kepala madrasah tersebut memberkan perhatian penuh kepada guru terkait pengembangan guru itu sendiri.

Terlepas dari apa yang dilakukan seorang guru yang memiliki kinerja yang tinggi juga tidak kalah pentingnya di lihat dari Output-nya ataupun prestasi peserta didiknya. Sebagaimana yang telah dikemukan oleh Supardi (2016: 55-556) yang mengatakn bahwa kinerja seorang guru dapat dilihat dari keluar madrasah ataupun produk madrasah itu sendiri. Kinerja guru yang baik akan menghasilkan peserta didik yang berprestasi. Sebagaimana yang diketahui bahwa peserta didik Madrasah Aliyah Pondok Pesantren Al-Ikhlas Ujung Bone seringkali mendapatkan sebuah kesempatan untuk menlajutkan studi S1 di berbagai perguruan tinggi yang terbaik, baik itu di dalam negeri maupun diluar negeri dengan menggunakan jalur undangan. Sehingga tidak heran jika peserta didik mereka mendapatkan jalur undangan itu, karena gurunya memiliki kinerja yang tinggi.

Berdasarkan dari hasil analisis angket yang menujukkan bahwa kinerja guru di Madrasah Aliyah Pondok Pesantren Al-Ikhlas Ujung Kecamatan Dua Bocco'e dapat dikategorikan tinggi, artinya dari sekian jumlah pernyataan angket tersebut sekitar 20 dari 6 dimensi yaitu, perencanaan pembelajaran, penguasaan bahan materi, penguasaan metode dan strategi, pemberian tugas, pengelolaan kelas, penilaian dan evaluasi pembelajaran. Dari keseluruhan dimensi kinerja guru faktanya dilapangan dari analisis pernyataan angket masih ada belum maksimal. Contohnya dari dimensi penguasaan metode dan strategi dari indikator "sebelum pembelajaran dimulai, saya terlebih dahulu tidak menarik perhatian peserta didik", dan dimensi penilaian dan evaluasi dari indikator "saya memperlihatkan jenis-jenis penilaian yang saya akangunakan kepada peserta didik". Sehingga inilah yang menjadi dasar mengapa kinerja guru berada dikategori tinggi, bukan sangat tinggi, sedang, rendah, dan sangat rendah, karena masih adan sedikit indikator yang belum maksimal diperlihatkan oleh guru.
3. Korelasi
Gaya Kepemimpinan Kepala Madrasah dengan Kinerja Guru di Madrasah Aliyah Pondok Pesantren Al-Ikhlas Ujung Kec. Dua Bocco'e Kab. Bone 
Korelasi antara gaya kepemimpinan kepala madrasah dengan kinerja di Madrasah Aliyah Pondok Pesantren AlIkhlas Ujung Kecamatan Dua Bocco'e Kabupaten Bone berdasarkan hasil analisis korelasi product moment diperoleh nilai $r x_{1} y$ sebesar 0,292. Angka indeks korelasi product moment tersebut menunjukkan korelasi positif karena mengikuti garis lurus yang ditandai dengan peningkatan nilai pada variabel gaya kepemimpinan kepala madrasah $\left(\mathrm{X}_{1}\right)$ diikuti dengan peningkatan nilai pada variabel kinerja guru (Y) sehingga memiliki hubungan linear yang searah meskipun terlihat lemah.

Tingkat korelasi antara gaya kepemimpinan kepala madrasah dengan kinerja guru yang diperoleh jika dikonsultasikan dengan tabel interpretasi koefisien korelasi,angka 0,292 berada pada interval 0,20 - 0,399, sebagaimana tercantum pada tabel berikut:

\begin{tabular}{|c|c|c|}
\hline $\begin{array}{c}\text { Nilai } \\
\boldsymbol{r}_{\boldsymbol{x}_{1} \boldsymbol{y}}\end{array}$ & $\begin{array}{c}\text { Interval } \\
\text { Koefisien }\end{array}$ & Tingkat Korelasi \\
\hline & $0,00-0,199$ & Sangat Rendah \\
& $\mathbf{0 , 2 0}-\mathbf{0 , 3 9 9}$ & Rendah \\
$\mathbf{0 , 2 9 2}$ & $0,40-0,599$ & Sedang \\
& $0,60-0,799$ & Kuat \\
& $0,80-1,000$ & Sangat Kuat \\
\hline
\end{tabular}

Tabel 4.10 Interpretasi Koefisien Korelasi Gaya Kepemimpinan Kepala Madrasah dengan Kinerja Guru

Tabel interpretasi koefisien korelasi tersebut menunjukkan bahwa hubungan antara gayakepemimpinan kepala madrasah dengan kinerja guru berada pada tingkat hubungan yangrendah. Hasil penelitian ini sejalan dengan penelitian yang dilakukan oleh Hagi EkaGusman (2014: 299-300) yang juga menemukan bahwa gaya kepemimpinan kepalamadrasah memiliki hubungan yang rendah dengan kinerja guru, bahkan hasil korelasiyang ditemukannya lebih rendah, yaitu 0,25. Lebih lanjut, penelitian ini juga sejalandengan penelitian Sri Setiyati (2014: 205) yang menunjukkan adanya hubungan yangrendah antara gaya kepemimpinan kepala madrasah dengan kinerja guru dengan nilaikoefisien korelasi 0,288. Meskipun demikian, kinerja guru ada hubungannya dengan gayakepemimpinan kepala madrasah sehingga gaya kepemimpinan kepala madrasah perluterus ditingkatkan agar kinerja guru juga dapat meningkat. Dengan demikian, terdapatkorelasi antara gaya kepemimpinan kepala madrasah dengan kinerja guru di MadrasahAliyah Pondok Pesantren AlIkhlas Ujung Kecamatan Dua Bocco'e Kabupaten Bonedapat diterima atau terbukti kebenarannya meskipun tingkat hubungannya rendah.

Berdasarkan hasil penelitian tersebut memberiakn sebuah kesimpulan bahwa gaya kepemimpinan kepala madrasah dengan kinerja guru memiliki sebuah hubungan meskipun hubungan tidak terlalu kuat, akan tetapi tetap masih ada hubungannya yaitu rendah. Hal ini sesui apa yang telah disampaikan oleh Ester Malik dan Kamal Bustomi (2014: 100) dalam jurnalnya yang di dalamnya mengatakn bahwa kinerja guru akan optimal bila diintegrasikan dengan beberapa komponen yang ada di dalam madrasah itu sendiri. Salah satunya ialah kepemimpina kepala madarsah. Pada dasarnya ada beberapa yang dapat memengaruhi kinerja guru dalam menjalankan tugasnya sebagai pendidik, salah satunya ialah kepemimpinan kepala madrasah. Sehingga akan terlihat jelas bahwa gaya kepemimpinan kepala madrasah akan ikut menentukan baik buruknya kinerja guru. Dengan demikian, gaya kepemimpina dan fasilitas yang ada di madrasah sangat berpengaruh pada kinerja guru. 


\section{PENUTUP}

\section{Kesimpulan}

a. Gaya Kepemimpinan Kepala Madrasah di Madrasah Aliyah Pondok Pesantren Al-Ikhlas Ujung Boneberada pada kategori baik dengan persentase sebesar $82,25 \%$ dari kriteria yang ditetapkan.

b. Kinerja guru di Madrasah Aliyah Pondok Pesantren Al-Ikhlas Ujung Bone berada pada kategori tinggi dengan persentase sebesar $84,21 \%$ dari kriteria yang ditetapkan.

c. Korelasi gaya kepemimpinan kepala madrasah dengan kinerja guru di Madrasah Aliyah Pondok Pesantren Al-Ikhlas Ujung Bone menunjukkan korelasi positif meskipun tingkat hubungannya rendah dengan nilai koefisien korelasi sebesar 0,292.

\section{Implikasi Penelitian}

a. Kepala madrasah diharapkan dapat terus berupaya untuk memaksimalkan

kepemimpinan

gaya diterapkannya serta berupaya untuk terus menciptakan iklim yang kondusif agar warga madrasah merasa nyaman dalam melaksanakan tugasnya masingmasing.

b. Guru-guru di madrasah diharapkan dapat agar dapat berupaya untuk terus mengembangkan kemampuannya dalam proses pembelajaran serta diharapakan dapat ikut membantu untuk menciptakan iklim madrasah yang kondusif.[]

\section{DAFTAR RUJUKAN}

Baharuddin, dan Umiarso. Kepemimpinan Pendidikan Islam: Teori dan Praktik. Cet. I; Yogyakarta: Ar-Ruzuzz Media, 2012.

Gusman, Hagi Eka. "Hubungan Gaya Kepemimpinan Kepala Sekolah dengan Kinerja Guru di SMP N Kecamatan Palembayan Kabupaten Agam." Jurnal Bahana Manajemen Pendidikan 2.1 (2014): 293-301.

Hasanah, Aan. Pengembangan Profesi Guru. Cet. I; Bandung: Pustaka Setia, 2012.

Irianto, Agus. Statistik; Konsep Dasar, Aplikasi, dan Pengembangannya . Cet. VII; Jakarta: Kencana, 2010.

Karweti, Engkay. "Pengaruh kemampuan manajerial kepala sekolah dan faktor yang mempengaruhi motivasi kerja terhadap kinerja guru SLB di Kabupaten Subang." Jurnal Penelitian Pendidikan 11.2 (2010): 77-89.

Kementerian Agama RI, Al Qur'an dan Terjemahnya. Cet. X; Bandung: Mikraj Khazanah Ilmu, 2014.

Mania, Sitti. Metodologi Penelitian Pendidikan dan Sosial. Cet. I; Makassar: Alauddin University Press, 2013.

Manik, Ester, and Kamal Bustomi. "Pengaruh Kepemimpinan Kepala Sekolah, Budaya Organisasi Dan Motivasi Kerja Terhadap Kinerja Guru Pada SMP Negeri 3 Rancaekek." Jurnal Ekonomi, Bisnis \& Entrepreneurship 5.2 (2011): 97-107.

Masaong, Abdul Kadimdan Arfan A. Tilome. Kepemimpinan Berbasis Multiple Interlligence: Strategi Kecerdasan Intelektual, Emosional dan Spiritual untuk Meraih Kesuksesan yang Gemilang. Cet. II; Bandung: Alfabeta, 2011.

Mavianti. "Hubungan antara Komunikasi Interpersonal Atasan-Bawahan dan Persepsi Terhadap Gaya Kepemimpinan Kepala Sekolah 
dengan Kepuasan Kerja Guru SMA Muhammadiyah 2 Tanjung Sari Medan." Jurnal Agama dan Pendidikan Islam, 10.1 (2018): 93-116.

Mudlofir, Ali. Pendidikan Profesional: Konsep, Strategi dan Aplikasinya dalam Peningkatan Mutu Pendidikandi di Indonesia. Cet. III; Jakarta: RajaGrafindo Persada, 2014.

Mulyasa, E.. Manajemen Berbasis Sekolah: Konsep, Strategi, dan Implementasi. Cet. XV; Bandung: Remaja Rosdakarya, 2014.

Ruliana, Poppy. Komunikasi Organisasi: Teori dan Studi Kasus. Cet. II; Jakarta: RajaGrafindo Pers, 2016.

Sagala, Syaiful. Administrasi Pendidikan Kontemporer. Cet. IV; Bandung: Alfabeta, 2008.

Setiyati, Sri. "Pengaruh kepemimpinan kepala sekolah, motivasi Kerja, dan budaya sekolah terhadap kinerja guru." Jurnal Pendidikan Teknologi dan Kejuruan, 22.2 (2014): 200-206.

Shihab, M. Quraish. Tafsir Al-Misbah: Pesan, Kesan dan Keserasian alQur'an. Cet.V; Jakarta: LenteraHati, 2009.

Siswanto, B. Pengantar Manajemen Cet. VI; Jakarta: Bumi Aksara, 2010.

Sugiyono.Metode Penelitian Kuantitatif, Kualitatif, dan R\&D. Cet. XXI; Bandung: Alfabeta, 2016.

Sukardi, Metode Penelitian Pendidikan. Cet. XII; Jakarta: BumiAksara, 2013.

Supardi. Kinerja Guru. Cet. III; Jakarta: Rajawali Pers, 2016.

Supardi. Sekolah Efektif: Konsep Dasar dan Praktiknya. Cet. I; Jakarta: Raja Grafindo Persada, 2013.

Susanto, Ahmad. Manajemen Peningkatan Kinerga Guru: Kosep, Strategi, dan Implementasi, Jakarta: Kencana, 2016.
Teryy, George R.. Principles of Management, Terj. G.A. Ticoalu, Jakarta: Bumi Aksara, 2010.

Umar, Bukhari. Ilmu Pendidikan Islam. Cet. II; Batusangkar: Amzah, 2011.

Wahab, Abdul Azis. Anatomi Organisasi dan Kepemimpinan Pendidikan. Cet. II; Alfabeta: Bandung, 2011.

Widyatono, Herry. Pengembangan Kurikulum di Era Otonomi Daerah. Cet. I Jakarta: Bumi Aksara, 2014.

Yulk, Gary. Kepemimpinan dalam Organisasi, Edisi Ketujuh Seri Bahasa Indonesia. Jakarta: Indeks, 2015.

Zainal, Veithzal Rivai dan Arviyan Arifin. Islamic Leadership: Membangun Super Leadership Melalui Kecerdasan Spiritual. Cet. II; Jakarta: Bumi Aksara, 2013.

Zainal, Veithzal Rivai, dkk. Kepemimpinan dan Perilaku Organisasi, Edisi Keempat. Cet. XII: Jakarta: Rajawali Pers, 2017. 